\title{
EVALUATION OF TAXATION PROVISIONS ON TRANSACTIONS E-COMMERCE ON THE MARKETPLACE PLATFORM
}

\author{
Posma Leonardo ${ }^{1 *}$ and Christine Tjen ${ }^{2}$ \\ ${ }^{1,2}$ Universitas Indonesia, Depok, Indonesia
}

\begin{abstract}
This research is based on the problem of the development of transactions ecommerce that do not necessarily boost state revenues from the taxation sector. The Directorate General of Taxation has made an affirmation regarding e-commerce by issuing SE-62 / PJ / 2013 dated December 27, 2013 concerning Affirmation of Provisions on Taxation of Transactions E-commerce, where transactions e-commerce are subject to the same tax as conventional business actors. This study aims to analyze the application of SE-62 / PJ / 2013 at PT Bukalapak.com and provide recommendations to PT Bukalapak.com related to the taxation aspect of transactions e-commerce. The object of the research is PT Bukalapak.com with the Tax Division as a unit of analysis. The research instrument uses interviews with PT Bukalapak.com and questionnaires to sellers who transact using the marketplace platform. The conclusion of the study is that PT Bukalapak.com does not implement or apply specific provisions for users of the Bukalapak application, this refers to the taxation system carried out in Indonesia, namely self assessment. Lack of tax knowledge on taxation obligations causes less success in maximizing tax payments on transactions e-commerce. PT Bukalapak.com has the initiative to become a partner of the taxation authority.

Keywords: E-commerce, Platform Marketplace, Taxation, Transaction
\end{abstract}

\section{INTRODUCTION}

Information technology has been successful in developing business transaction processes. One of them is that prospective buyers no longer need to come to the store to buy a product, only by using a smartphone they can buy the desired product. This activity is known as online transactions or e-commerce. Online business / commerce is a business activity that uses internet and information technology.

E-commerce helps companies to expand market share at the national level and expand business throughout the country. Online business has its own advantages compared to conventional, the use of technology in online business makes it easy for aspiring entrepreneurs to start their business (Testa, 2017).

In an article in the online newspaper Kompas.com explains some of the advantages in online business. First, the relatively low investment value; the main investment is only for goods sold, it doesn't need a lot of money to build a shop or rent an annual kiosk. Second, the main working capital is in the internet connection, computers, and the goods and services offered. Third, the risk of online business investment is also low, free business owners improvise to find the most appropriate products and the best way to market their business. Fourth: potential customers reach millions of people. Fifth, the cost of setting up an online store is lower than an offline store, on the platform it ecommerce does not charge registration fees or the establishment of a shop (Dini, 2011).

The increase in e-commerce transactions has a positive impact on the country's economy. This was stated by the Governor of the Bank of Indonesia (BI) Agus Martowardojo stated that the improvement of digital technology in economic activities could drive growth above national economic growth (Nababan, 2017). The Government through the Directorate General of Taxes (DJP) has regulated e-commerce transactions by issuing SE-62 / PJ / 2013 dated December 27, 2013 concerning Affirmation of Taxation Provisions for E-Commerce Transactions, which states that the taxation treatment of e-commerce transactions is the same as conventional transactions.

* Corresponding author. Email address: posmaleonardo@gmail.com 
Therefore, the seller or buyer may be taxed in accordance with applicable tax laws. The potential taxation arising from online transactions can be of the type of Value Added Tax (VAT) and Income Tax. Taxes on e-commerce transactions aim to apply justice to all conventional and e-commerce taxpayers. Thus the increase in e-commerce transactions is naturally proportional to the tax increase from Value Added Tax and Income Tax.

Based on the SEA 2018 eConomy report released by Google Temasek, e-commerce is the fastest growing sector of digital economic activity. During 2018 digital economy activities in Indonesia reached US \$ 27 billion and will continue to grow to US \$ 100 billion by 2025 (Google \& TEMASEK, 2018). The Executive Director of the Center for Indonesia Taxation Analysis (CITA), Yustinus Prastowo, if the Directorate General of Taxation is cannot collect taxes from this sector, the country loses tax potential of up to $10 \%$ of transactions (Setyowati, 2017). So that problems arise, the existing provisions have not been sufficiently successful in maximizing taxes on e-commerce transactions.

Previous research has been conducted on the application of taxation aspects to ecommerce transactions. Taxes on sales generally occur when the seller and buyer are in the same country, and the seller can be an extension of the government in tax collection (Barsade \& Elyashiv, 2009). Taxation policy based on region and jurisdiction becomes a problem in determining the potential for taxation in e-commerce transactions, because it is difficult to determine the location of sellers and buyers on transactions conducted through the internet so that it can be concluded that trading transactions over the internet without restrictions can cause problems in the application of taxation (Yapar, Bayrakdar, \& Yapar, 2015). There are difficulties in taxing e-commerce transactions, so special rules are needed to regulate e-commerce transactions to increase tax revenue from the sector. (Sari, 2018). Naicker in his research stated that e-commerce is a global business revolution and economic culture, so the government and tax authorities need to develop a taxation framework for e-commerce (Naicker, 2003).

This research was conducted by researchers to study and answer the problem formulation as follows:

1. How is the application of SE-62 / PJ / 2013 in PT Bukalapak.com according to attribution theory?

2. How does Seller apply tax provisions based on SE-62 / PJ / 2013 for transactions conducted on the marketplace platform according to attribution theory?

3. How to supervise taxation of transactions e-commerce conducted by PT Bukalapak.com based on supervision theory?

This research aim to:

1. Analyze the application of SE-62 / PJ / 2013 in PT Bukalapak.com according to attribution theory.

2. Analyze the application of SE-62 / PJ / 2013 by sellers who make transactions on the marketplace platform according to attribution theory.

3. Analyzing tax control overtransactions e-commerce conducted by PT Bukalapak.com.

This research is a case study and uses an approach mixed-method. The use of mixed methods is a combination of quantitative methods and qualitative methods so as to produce more accurate data.

The researcher hopes that the research can provide benefits and suggestions that can be used as an evaluation and analysis of the SE-62 / PJ / 2013 application dated December 27, 2013 concerning Affirmation of Taxation Provisions for E-Commerce Transactions that occur on the market platform, PT Bukalapak.com and provide recommendations on the taxation aspects of e-commerce transactions to marketplace platform providers.

Prior Study. Previous studies have been carried out by previous researchers regarding the application of aspects of taxation to e-commerce transactions. Taxes on sales generally occur when sellers and buyers are in the same country, and sellers can be an extension of the government in tax collection (Barsade \& Elyashiv, 2009). Taxation policies based on regions and jurisdictions have problems in making taxation in e- 
commerce transactions, because it is difficult to determine the location of sellers and buyers on transactions conducted via the internet so it is concluded that buying and selling transactions via the internet without restrictions can cause problems in taxation (Yapar et al., 2015). Because of this difficulty in taxing e-commerce transactions, special rules are needed to regulate e-commerce transactions to increase tax revenue from the sector (Sari, 2018).

E-commerce transactions are a challenge in tax policy, because they can lead to debate in the taxation and double tax authorities, until the Organization for Economic Co-operation and Development (OECD) regulates them in the Tax Treaty(Cockfield, 2006). Taxation in e-commerce is a global challenge for the government and business people so that a tax framework is needed to keep up with the development of ecommerce businesses (Naicker, 2003). In India the implementation of Good and Service Tax enhances the framework of the tax assessment that impacts on e-commerce in the country (Anand \& Bhraguram, 2017)

Research with the title "Treatment of VAT on E-Commerce Transactions", this study aims to analyze the treatment of Value Added Tax (VAT) for e-commerce transactions. The study states that online transactions are included in the e-commerce category because each stage is both a process of buying and selling products or services that are done electronically by utilizing internet technology. The study states that ecommerce can be categorized as the distribution or marketing of services through electronic systems such as the internet or other computer networks. E-commerce also involves electronic funds transfers, inventory management systems and automated data collection systems. The study links Value Added Tax due to taxes arising from each value added for factors that occur starting from preparing to selling goods or services to buyers. The results of the study state that e-commerce transactions are no different from conventional transactions, so they still have Value Added Tax obligations (Lomanto \& Mangoting, 2013).

Previous research entitled "Revealing the Issues of E-Commerce Taxation in Indonesia and the Solution to the Solution". The aim of the study was to provide feedback on taxation in Indonesia with various types of assessments and how to overcome tax loopholes in e-commerce activities. The study states that the principle of e-commerce transactions is the same as other transactions, but different in the way and tools used. The study describes the form of e-commerce in Indonesia according to the rules SE-62 / PJ / 2013 divided into four groups, namely:

- Classified Ads, is a classified ad site, but there are no online transaction activities. Examples such as: olx.co.id, rumah123.com

- Marketplace, this business model provides a place of business activities such as an online mall as a place to sell goods and services. So that the website provider is not the owner of the goods being traded. Examples such as: Bukalapak, Tokopedia, Shopee

- Retail Online, this business model is an online store that has its own web address, so that activities to sell goods or services are carried out by retail providers. Examples include: Blibli, Bhinneka.com, Alfamart

- Daily deals, in the form of sites that provide sales of vouchers as a means of payment for transactions of goods or services. Examples such as: Groupon, Lakupon.

The results of the study indicate that it is necessary to establish a supervisory body for e-commerce transactions through world-class website traffic, so that human resources are needed in this field (Pangesti, 2017).

In a study entitled "E-Commerce Transactions as a Potential Tax Revenue in Indonesia" published by the Indonesian Tax Journal, it aims to determine the potential tax revenue from e-commerce transactions in Indonesia. In this study the researchers explained that in Indonesia, because there is still no proper regulation on e-commerce transactions so that it can cause a loss of potential tax revenue. The results of the study suggested that the Directorate General of Taxes collaborate with related parties such as APJII and the Ministry of Communication and Information to consider tax regulations 28 
on e-commerce transactions, pay attention to effective tax collection systems and converge with international standards in avoiding double taxation (Utomo, 2017).

On December 31, 2018, the Minister of Finance of the Republic of Indonesia established the Minister of Finance Regulation of the Republic of Indonesia number 210 /PMK.010/2018 concerning Tax Treatment of Trade Transactions through the Electronic System (e-Commerce) which took effect on April 1, 2019. obligation to sell goods or services in the marketplace platform and provider of marketplace platforms. But before the enactment of PMK-210 / PMK.010 / 2018, on March 29, 2019, the Minister of Finance announced the withdrawal of the provisions (Pramesti, 2019). The PMK regulates the technical provider of platform marketplace to pay and report income tax and VAT for services performed as well as provisions related to tax obligations for sellers of products or services on the marketplace platform. The regulation only regulates e-commerce transactions on the marketplace platform, while transactions carried out through social media are not regulated in detail.

\section{Theoretical basis.}

Attribution Theory presents a framework that aims to provide an understanding of how each individual evaluates his own behavior and the behavior of others. Attribution theory states that individuals seek an explanation of the events that occur to them and those around them (Schisler \& Galbreath, 2015). The theory-related study was first conducted by Fritz Heider in 1958. Heider (1958) in Sukarma (2016) states that each individual is a scientist who tries to understand and understand the behavior of others through gathering information so that he can obtain a reasonable explanation about cause-effect of other people's behavior (Sukarma \& Wirama, 2016). In the process of understanding your paper and style, you will try to determine the cause of the behavior, whether internal / external or external.

Robbins (2008) in Sukarma (2016) states that there are three things in determining internal or external factors (Sukarma \& Wirama, 2016), namely:

a. Specificity

If someone will perceive differently from other people's behavior when different situations occur. For example, if someone does an extraordinary action then it is classified as external attribution. And vice versa, when doing things that are considered biased, they will be assessed as internal attribution.

b. Consensus

If everyone has the same view in responding to someone's behavior in the same situation. If contribution is high, it will be in internal attribution. But if the contribution is low then it will be classified into external attribution.

c. Consistency

If a person evaluates the behavior of others with the same response from time to time. The more consistent the behavior will be attributed to internal attribution.

Hite (1987) in Schisler and Galbreath (2015) states that in line with attribution theory found that there is a relationship between tax avoidance behavior and external factors when making taxpayer avoidance observations with taxpayer personal factors (Schisler \& Galbreath, 2015). In the development of Attribution theory, Weiner combines the factors put forward by Heider and Rotter, namely internal factors (ability and effort) and external factors (difficulty and luck) (Weiner, 2012). This research uses attribution theory, because the willingness of the public or taxpayers to implement tax provisions related to the perception of the tax itself.

\section{RESEARCH METHODOLOGY}

This study uses a mixed-method approach. Mixed methods can be used in research when in the process researchers use quantitative and qualitative data, where the use of these types of data can provide a better understanding of research problems (Kurniasih, 2015). Mixed research is used when researchers see that the use of quantitative and 
qualitative methods will be very useful for answering existing research questions (Shauki, 2018b).

The data used in this study are primary data. Primary data are the results of interviews with PT Bukalapak.com, as well as the results of questionnaires to sellers who make sales transactions using the marketplace platform and questionnaires to sellers who transact using the marketplace platform.

This study establishes PT Bukalapak.com as an object in this study because PT Bukalapak.com can answer the research question in this study. PT Bukalapak.com is a member of the Indonesian E-Commerce Association (IdEA). This study uses interviews and questionnaires as research instruments. Interviews were conducted to obtain relevant information regarding research problems. Interviews were conducted with Bukalapak.com on the part responsible for reporting and taxation of PT Bukalapak.com. The interview process begins with submitting an interview permit letter to PT Bukalapak.com HRD, as well as requesting competent employee data to become a resource person. Then submit a request to hold a meeting for an interview. The interview was conducted on Tuesday, April 23, 2019 at the PT Bukalapak.com office location. The informants appointed by PT Bukalapak.com are Senior Tax Manager and R2P with 1 year and 7 months working period at PT Bukapalak.com and Tax Supervisor with 1 year and 4 months working period at PT Bukalapak.com. The interview technique used is semi-structured interviews (Shauki, 2019).

The questionnaire was conducted to obtain relevant information regarding research problems. The questionnaire was conducted using an online survey tool with Survey Monkey media. Questionnaires are conducted to sellers who conduct e-commerce transactions through the marketplace platform. The selection of sellers participating in the questionnaire is the seller in the Nintendo Buying and Selling Forum that sells goods / products with transactions using a marketplace platform such as Bukalapak. The questionnaire contains how long they have been active in sales through e-commerce as well as a basic understanding of tax obligations. The questionnaire was conducted from March 14, 2019 to April 25, 2019. The questionnaire was sent using email, Facebook Messenger and Whatsapp by sending the questionnaire link. There were 65 respondents who had filled out a survey of 80 sellers. Questionnaire questions consisted of 10 questions with 4 being closed ended questions and 6 being open ended questions.

Data Analysis. This research in the analysis data uses the Content Analysis approach. According to Wilkinson and Birmingham (2003) in Shauki (2018), content analysis can be used in both quantitative and qualitative approaches to conduct analysis (Shauki, 2018a).

The case study in this study is a single case study. While the object of the research was PT Bukalapak.com, a start up company that provides a "market" for online transactions both through websites and applications that can be obtained from the App Store or Google Play. The Bukalapak application is one of the e-commerce startups in Indonesia that has succeeded in getting the title of unicorn. As well as ecommerce sellers who transact using the marketplace platform.

\section{RESULTS AND DISCUSSION}

In this chapter, we discuss the results and discussion to answer the questions from this study as follows (1) how is the application of SE-62 / PJ / 2013 in PT Bukalapak.com according to attribution theory, (2) how does Seller apply tax provisions based on SE-62 / PJ / 2013 for transactions conducted on the marketplace platform according to attribution theory, and (3) how to supervise taxation of transactions ecommerce conducted by PT Bukalapak.com based on supervision theory.

Results. This study uses a research approach with case studies. In this study, in the analysis of data using the content analysis approach, by paying attention to the words of each word taking into account the main topics carried out. The data used uses primary 
data, using research instruments in the form of interviews and questionnaires. In processing data researchers use Nvivo 12 software using tools words frequency.

Interview. The interview was conducted at PT Bukalapak.com. With the Tax Division from PT Bukalapak.com. The interview was conducted to PT Bukalapak.com, because according to PT Bukalapak.com researchers could answer the research question from this study. PT Bukalapak as a member of the Indonesian E-commerce Association (IdEA), also places its representatives in the management of IdEA.

Here's a list of questions in the interview:

- How are the stages / processes carried out by prospective sellers to be able to transact in the Bukalapak application?

- Are there certain conditions for becoming a seller in the Bukalapak application?

- How does Bukalapak validate or verify data submitted by prospective sellers?

- Can foreign or Indonesian domiciled abroad become sellers in the Bukalapak application? If yes, are there special provisions?

- According to SE-62 / PJ / 2013 dated December 27, 2013 concerning Affirmation of Provisions on Taxation on E-Commerce Transactions, which states that there are no new taxes in e-commerce transactions. What is Bukalapak's view of this?

- As of December 31, 2018, Minister of Finance Regulation Number 210 / PMK.010 / 2018 has been stipulated concerning the Taxation Treatment for Trade Transactions through Electronic Systems (E-Commerce), which regulates the provider of platform marketplace. Did Bukalapak know about this?

- Before the revocation of PMK 210/2018 was announced, what preparations had been made by Bukalapak?

- Do you think that a special tax for e-commerce transactions is needed?

- Do marketplace platforms need to be involved in overseeing taxation of ecommerce transactions?

- What is Bukalapak's hope for the Directorate General of Tax regarding taxation supervision on E-commerce transactions?

- Is Bukalapak's advice and input on the Directorate General of Tax regarding tax supervision on E-commerce transactions?

- In the last 5 years ecommerce transactions have shot up but not accompanied by tax growth. How do you think about this?

Based on questions about the stages / processes carried out by prospective sellers to be able to transact in the Bukalapak application. Respondent B explained that the stages carried out by prospective sellers to be able to transact in the Bukalapak application by creating an account in the Bukalapak application by simply registering the email address and telephone number of the prospective seller.

Based on questions regarding specific provisions or certain conditions for selling in the Bukalapak application. Respondent stated that there were no special conditions for selling in the Bukalapak application, in the application it offered the convenience to transact and sell through the platform.

Questions about how the platform performs validation or verification of data submitted by prospective sellers. Respondent stated that Bukalapak continued to apply the validation process for the e-mail address and telephone number for the registration process for creating a new account in the application.

Questions about foreign nationals or Indonesian citizens domiciled outside Indonesia become sellers in the Bukalapak application. Respondent stated that Bukalapak can be used by anyone, whether foreign citizens or Indonesian citizens domiciled in Indonesia as long as they fulfill the requirements in the account creation process.

Questions about Bukalapak's view towards SE-62 / PJ / 2013 dated December 27, 2013 concerning Affirmation of Taxation Terms for E-Commerce Transactions. 
Respondent stated that provisions for new types of tax on e-commerce transactions were not needed, because basically they were the same as conventional transactions.

The question is whether Bukalapak knows about the Minister of Finance Regulation Number 210 / PMK.010 / 2018 concerning the Tax Treatment of Trade Transactions through Electronic Systems (E-Commerce) which should take effect on April 1, 2019. Respondents stated that Bukalapak knew about the issuance of taxation on e-commerce but was quite shocked at the time the regulation was issued because it felt that the rule was not final.

Questions about the preparations that have been made by Bukalapak relate to the application of the Minister of Finance Regulation Number 210 / PMK.010 / 2018. Respondent stated that Bukalapak was waiting for the implementation rules for PMK210 / PMK.010 / 2018 so that there was no special preparation.

Questions about the urgency to do a special tax for e-commerce transactions. Respondent stated that Bukalapak stated that the determination of special taxes on ecommerce transactions could potentially conflict with the existing system.

Questions about involving the marketplace platform in monitoring taxation on ecommerce transactions. Respondent stated that Bukalapak offered to carry out socialization of tax obligations for e-commerce players. Besides offering themselves to be an ASP (Active Server Page) which is given access to be a means of reporting and payment of taxes.

Questions about Bukalapak's expectations of the Directorate General of Tax concerning taxation supervision on E-commerce transactions. Respondent stated that there was a need for equality in tax supervision on e-commerce transactions both on platforms and social media..

Questions about Bukalapak's advice and input to the Directorate General of Tax concerning taxation supervision on e-commerce transactions. Respondent stated that tax provisions must be balanced for all types of activities not only the marketplace platform is regulated.

Questions about Bukalapak's opinion on the increase in e-commerce transactions are not comparable with tax growth. Respondent stated that public knowledge of taxes is still an obstacle, it is necessary to change the paradigm of the community towards taxes. Because of that, it needs improvement in terms of socialization to increase public awareness.

The researcher used the Content Analysis method by using Nvivo 12 software based on the word frequency so that the words that often appeared in the interview data were obtained. Based on the word frequency result there are 1,019 words, researchers eliminate words that have no meaning and are not related to the topic. This shows that respondents emphasized and gave important things to this. Respondents put emphasis on taxes, transactions, platforms, socialization, ecommerce sellers, marketplace.

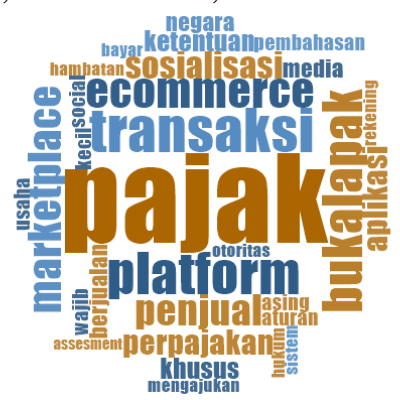

Figure 1 Word Cloud Interview

Questionnaire. The questionnaire was conducted using an online survey using Survey Monkey. Questionnaires were carried out to sellers at the Nintendo Indonesia Buying and Selling Forum who made sales transactions using the marketplace platform. There were 65 respondents who had filled out questionnaires from 80 sellers. Questionnaire 
questions consist of 10 questions with 4 close-ended questions and 6 open-ended questions.

The following questions in the questionnaire:

- How long have you been selling online using a platform marketplace (Tokopedia, Bukalapak, Shopee, etc.)?

- In which marketplace platform do you sell products or services??

- Do you also sell products or services offline (have a physical store or trade with conventional methods)?

- Is it when you register to become a Merchant or Seller on the marketplace platform that special verification is carried out by the marketplace platform?

- Do you have a NPWP?

- In your opinion, what tax obligations do individuals who have a NPWP have to do?

- Do you think there is a connection between taxation and e-commerce transactions? Give your opinion.

- Do you agree if the platform market service provider is authorized to collect taxes on e-commerce transactions and report your transaction to the DJP? Give your opinion.

- Based on SE-62 / PJ / 2013 concerning Affirmation of Taxation Terms for ECommerce Transactions, states that the application of taxation on e-commerce transactions applies equally to conventional transactions. Do you agree on this? Give Your Opinion.

- How do you apply the provisions of SE-62 / PJ / 2013 to your e-commerce transactions in the marketplace platform?

The results of the questionnaire were analyzed by content analysis, using Nvivo by looking at the word frequency of the respondents' answers. Top of the query results using the cluster analysis display.

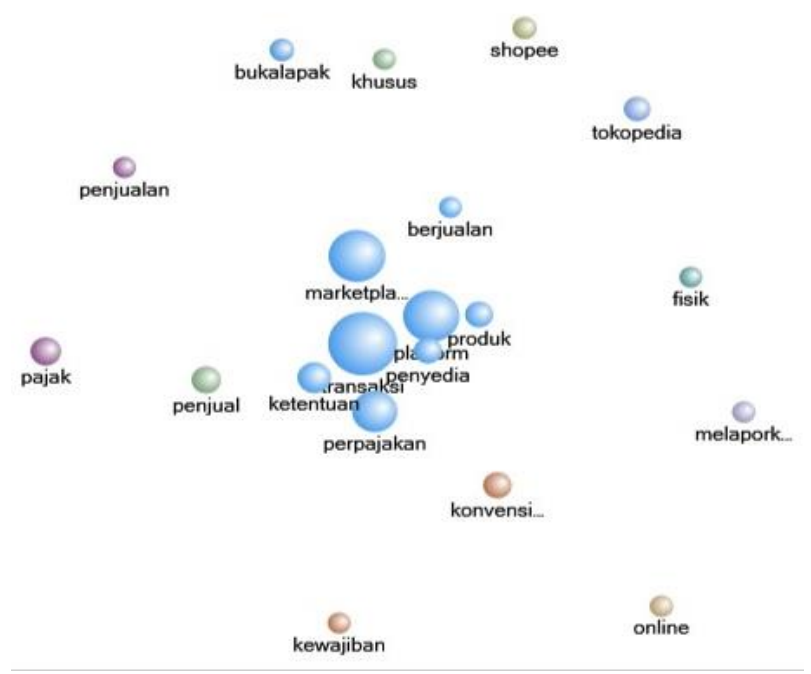

Figure 2 Result Cluster Analysis

In this section we will discuss the results, which were obtained from the analysis of the results of interviews and questionnaires, on the research questions.

How is the application of SE-62 / PJ / 2013 in PT Bukalapak.com according to attribution theory?

To answer this research question, the researcher conducted an interview with PT Bukalapak.com through the results of an interview with the Tax Division of PT Bukalapak.com. It was known that the company did not implement or provide specific provisions related to taxes on buying and selling transactions in its application, it refers 
to the taxation system carried out in Indonesia, self assessment. In this system the taxpayer is authorized by the tax authority to calculate, pay and report on its own tax obligations. So that the Income Tax or Value Added Tax that may occur in transaction activities then it is a personal taxation obligation of each related party. Because it is a personal obligation, no special application of tax obligations is required. On SE-62 / PJ / 2013 also stated that the application of taxation provisions on e-commerce transactions is the same as general tax provisions. Therefore, PT Bukalapak.com does not provide special conditions or conditions, including for foreign nationals who sell in the Bukalapak application.

In attribution theory there are factors that are taken into consideration in carrying out an action or act. For the formulation of this problem the data obtained from interviews and questionnaires fall into the category of Consensus value factors in attribution theory. It refers to how someone does the same actions or actions with other people in general (the majority), then the action has a high consensus. It was shown that not only Bukalapak but also other marketplace platforms did the same with regard to tax provisions for the application users. By not applying the provisions of SE-62 / PJ / 2013 specifically for users of the application both for sellers and buyers. One of the interesting information obtained in the interview process is that due to business competition in the marketplace platform high, the orientation reduces or even eliminates barriers for sellers or buyers to transact in their applications. In the absence of special provisions applied by the marketplace platform , the tax provisions contained in SE-62 / PJ / 2013 are not implemented.

How does Seller apply tax provisions based on SE-62 / PJ / 2013 for transactions conducted on the marketplace platform according to attribution theory?

To answer this research question obtained from the results of a questionnaire to ecommerce sellers in the marketplace. Based on the results of the questionnaire $26.56 \%$ of respondents who tried online did not have a NPWP, in question number 10 in the questionnaire the researchers asked that the application of SE-62 / PJ / 2013 as many as $51.51 \%$ stated negative sentiment by stating they had never done, did not understand or not understand, $30.30 \%$ stated positive sentiments by stating that they were in accordance with PP 23/46 or implementing the provisions and $16.67 \%$ did not answer the question.

The willingness of the public or taxpayers to implement tax provisions related to the perception of the tax itself, the negative sentiment contained in the results of the questionnaire shows the public perception of taxation. When the community does not yet have the correct understanding due to lack of information, it results in low awareness of taxation. This is the cause of "causal attribution".

Based on the formulation of the problem regarding the application of taxation provisions based on SE-62 / PJ / 2013 on transactions e-commerce on the marketplace platform by the seller according to attribution theory and based on data obtained through the research process, it can be seen that the majority of sellers have not carried out tax obligations in accordance with taxation provisions especially related to SE-62 / PJ / 2013.

How to supervise taxation of transactions e-commerce conducted by PT Bukalapak.com based on supervision theory?

To answer this question this study was obtained from the results of interviews with PT Bukalapak.com, based on the results of interviews obtained information if PT Bukalapak.com has the initiative to become a partner of the tax authority by submitting themselves as ASP, so that tax reporting and tax payments can be made through the Bukalapak application. When it can be done in the application, Bukalapak can encourage sellers in their application to report and pay their taxes. So as to help the tax authorities in the socialization of tax compliance to taxpayers.

The role of application providers that can be done that can contribute to tax revenue is to provide data reports feeding on transactions that occur on the platform to the tax authorities. So that the taxing authority can supervise business actors who run their 
businesses using the media platform marketplace. This is necessary considering the system self assessment on taxation in Indonesia needs to be balanced with a good tax supervision system.

Platform providers need to consider making NPWP as one of the provisions for sellers who will sell in their applications. This is due to the fact that transactions are online included in the Final Income Tax category for certain turnover so that they do not consider non-taxable income, the same as Final Income Tax on deposit interest, leasing rights on land and / or buildings.

In attribution theory the thing that drives PT Bukalapak.com in doing that behavior can be driven by obligation (feeling to do something) and being permitted (allowed to do something). Therefore it is necessary to have binding and obligatory provisions, because of transactions e-commerce there are no technical regulations governing it.

SE-62 / PJ / 2013 does not have permanent legal force, because. So it needs to be considered for the issuance of Regulation of the Director General of Tax or Regulation of the Minister of Finance. PT Bukalapak.com stated in an interview that it was ready to support every provision stipulated by the Government, but asked to continue to consider equal treatment, especially for foreign marketplace platforms that do not have permanent establishment in Indonesia and the social media that are widely used to sell online.

\section{CONCLUSIONS}

In this chapter we discuss the conclusions of the discussion of results and descriptions to answer some of the research questions discussed in the previous chapter.

To answer the research question (1) PT Bukalapak.com has a view that the taxation obligation is an individual obligation of each taxpayer, so it does not apply special provisions for the application of SE-62 / PJ / 2013 for the users of the application, it is also carried out by all marketplace platforms in the association.

To answer the research question (2) Most of the sellers who carry out transactions on the marketplace platform have not implemented tax obligations properly based on applicable regulations, the public's willingness or taxpayers to implement taxation provisions related to the perception of the tax itself, there are negative sentiments that indicate people's perceptions of taxation.

To answer the research question (3) Tax monitoring of transactions $e$-commerce providers marketplace platform has not been conducted. Internal supervision is carried out by providers marketplace platform on activities related to business processes ranging from registration to transactions, this is done for the convenience of users in using their applications and to avoid fictitious transactions that utilize Bukalapak promos and promotional programs.

Limitations. In this study has limitations that cannot be controlled by researchers. This research is only limited to transactions e-commerce that use the marketplace platform. The researcher also limited the distribution of questionnaires only to sellers who made transactions through the Buy and Sell Forum marketplace platform due to time constraints in conducting the questionnaire process. This study of transactions ecommerce in Indonesia, by conducting interviews with PT Bukalapak.com which can only be used in Indonesia's domicile.

Subsequent Research Proposal. Considering that e-commerce transactions are not only limited to the marketplace platform, researchers propose that further research be conducted on non-platform marketplace.

\section{References}

Anand, P., \& Bhraguram, T. M. (2017). Goods and Service Tax ( GST ) Impact of ECommerce in Indian Economy. EPH - International Journal of Business \& Management Science, (5), 9-20.

Barsade, J., \& Elyashiv, T. (2009). Integrated e-commerce sales \& use tax exchange 
EVALUATION OF TAXATION PROVISIONS ON TRANSACTIONS E-COMMERCE

ON THE MARKETPLACE PLATFORM

system and method.

Cockfield, A. J. (2006). THE RISE OF THE OECD AS INFORMAL "WORLD TAXORGANIZATION" THROUGH NATIONAL RESPONSES TO ECOMMERCE TAX CHALLENGES. Yale Journal of Law \& Technology, 24(1), $81-102$.

Dini. (2011). Bisnis Online: Modal Minimal, Keuntungan Maksimal - Kompas.com. [Online]. Available: https://lifestyle.kompas.com/read/2011/11/01/16170771/bisnis.online.modal.min imal.keuntungan.maksimal. [Accessed: 02-Apr-2019]

Google \& TEMASEK. (2018). e-Conomy SEA 2018.

Kurniasih, N. (2015). METODE CAMPURAN (MIXED METHODS) | nurafni retno kurniasih. [Online]. Available: http://retnoafni.blogspot.com/2015/11/metodecampuran-mixed-methods.html. [Accessed: 26-Feb-2019].

Lomanto, C. N., \& Mangoting, Y. (2013). Perlakuan PPN atas Transaksi E-Commerce. Tax \& Accouting Review, 3(2).

Nababan, C. N. (2017). Belanja Online Masyarakat Indonesia Tembus Rp75 Triliun. CNN Indonesia. [Online]. Available: https://www.cnnindonesia.com/ekonomi/20170809151902-78-233513/belanjaonline-masyarakat-indonesia-tembus-rp75-triliun. [Accessed: 02-Apr-2019].

Naicker, K. (2003). the Taxation of E-Commerce : an Examination of the Impact and Challenges Posed By Electronic Commerce on the Existing Tax Regime By Pietermaritzburg.

Pangesti, R. D. (2017). Menguak Permasalahan Perpajakan E-, 2(1), 181-201.

Pramesti, I. A. (2019). Pengumuman: Sri Mulyani Tarik Aturan E-Commerce, Batal Semua! [Online]. Available: https://www.cnbcindonesia.com/fintech/20190329160155-3763738/pengumuman-sri-mulyani-tarik-aturan-e-commerce-batal-semua. [Accessed: 04-Apr-2019].

Sari, R. P. (2018). Kebijakan perpajakan atas transaksi e-commerce. Akuntabel, 15(1), 67. https://doi.org/10.29264/jakt.v0i0.2889

Schisler, D. L., \& Galbreath, S. C. (2015). "Responsibility for tax return outcomes: An attribution theory approach" In Advances in Taxation. Emerald. https://doi.org/https://doi.org/10.1016/S1058-7497(00)12019-8

Setyowati, D. (2017). Belanja Online Naik, Potensi Pajak Hilang Rp 20 Triliun per Tahun Katadata News. [Online]. Available: https://katadata.co.id/berita/2017/08/03/belanja-online-naik-potensi-pajakhilang-rp-20-triliun-per-tahun. [Accessed: 20-Feb-2019].

Shauki, E.R. (2018). "Research Instruments in Case Study and the Role of Researcher", Handout, CASE WRITING AND METHODOLOGY, ECAM 809303, (Elvia T. Shauki, Phd) University of Indonesia. April 2018, Print.

Shauki, Elvia R. (2018). ENHANCING THE OUTCOME OF DATA ANALYSIS by USING MIXED-METHOD RESEARCH.

Shauki, Elvia R. (2019). CONVERTING YOUR MASTER / PhD THESIS INTO A JOURNAL ARTICLE : TO COPY and PASTE OR REWRITE ?, 1-8.

Sukarma, D. A., \& Wirama, D. G. (2016). Locus Of Control Sebagai Pemoderasi Pengaruh Kualitas Pelayanan dan Sanksi Perpajakan pada Kepatuhan Wajib Pajak. E-Jurnal Ekonomi Dan Bisnis Universitas Udayana. 
Testa, M. G. (2017). VAT treatment of E-commerce intermediaries Table of Contents.

Utomo, R. U. (2017). Tantangan pengawasan ppn atas transaksi konten digital. Jurnal Pajak Indonesia, 1-6.

Weiner, B. (2012). Handbook of Theories of Social Psychology: Volume 1 An Attribution Theory of Motivation. (P. Van Lange, A. Kruglanski, \& E. Higgins, Eds.) (Vol. $\quad 1)$ London: https://doi.org/http://dx.doi.org/10.4135/9781446249215.n8

Yapar, B. K., Bayrakdar, S., \& Yapar, M. (2015). The Role of Taxation Problems on the Development of E-Commerce. Procedia - Social and Behavioral Sciences, 195, 642-648. https://doi.org/10.1016/j.sbspro.2015.06.145 